Baizakova K.I., Yermekov A.B.

The Impact of Chinese

SLOC Development within International Security Trends

Байзакова К.И., Ермеков Ә.Б.

Қытай ТБК дамуының халықаралық қауіпсіздік тренді әсері

Байзакова К.И., Ермеков А.Б.

Воздействие развития китайских МАК в трендах межАународной безопасности
Geopolitical ascendancy of China as a growing superpower entails to the development of new tendencies in the area of the international security. Chinese policy on sustaining of the energy security and active search of various crudes led to the development not only a transport and logistical strategy, but also to the shifts within strategic environment, especially in area of the India Ocean. Chinese SLOCs (Sea Lines of Communication) in the contemporary period play a crucial role under shaping and development of tendencies in the sphere of regional security. The theme and nature itself of Chinese SLOCs have a complex character and cover such areas like a transportation and logistics, foreign policy and strategy, development of military forces and PLAN capabilities.

Key words: logistics and transportation, ports, tankers, PLAN (People`s Liberation Army Navy), strategy, energy.

Қытайдың алпауыт мемлекет ретінде геосаяси тұрғылан өрлеуі халықаралық қауіпсіздік саласында жаңа тенденциялардың дамуына алып келуде. Қытайдың энергетикалық қауіпсіздік және жаңа энергия қорларын белсенді іздестіру саясаты, оның тасымал және логистикалық, стратегиясының дамуына ғана алып келмей, стратегиялық, ортада, әсіресе Үнді мұхиты аймағындағы өзгерістерді тудырған болатын. Қазіргі таңда Қытайдың теңіздегі қатынас жолдары аймақтық қауіпсіздік саласындағы тенденциялардың қалыптасуы мен дамуында шешуші роль атқаруда. ҚХР-дың теңіздегі байланыс жолдары мәселесі мен оның табиғаты күрделі сипатқа ие бола отырып, оның тасымал және ^огистика, сыртқы саясат пен стратегия, қарулы күштердің дамуы мен ҚХАА әскери-теңіз фмотының мүмкінАіктері секілді тұстары бар.

Түйін сөздер: ^огистика және тасымал, порттар, танкерлер, ҚХРдың әскери-теңіз фмоты, стратегия, энергетика.

Геополитическое становление Китая как растущей державы приводит к развитию новых тенденций в области международной безопасности. Политика Китая по подАержанию энергетической безопасности и активного поиска различных энергоресурсов привела к развитию не только транспортной и ^огистической стратегии, но и к изменениям в стратегической среде, в особенности в районе Индийского океана. Китайские морские минии коммуникации в современный период играют кАючевую роль при формировании и развитии тенденции в области региональной безопасности. Сама тема и природа морских линий коммуникации КНР носит комплексный характер и охватывает такие стороны, как транспортировка и ^огистика, внешняя политика и стратегия, развитие вооруженных си^ и потенциал военно-морского флота НОАК.

Кмючевые слова: ^огистика и транспортировка, порты, танкеры, военно-морской флот КНР, стратегия, энергетика. 


\section{THE IMPACT OF CHINESE SLOC DEVELOPMENT WITHIN INTERNATIONAL SECURITY TRENDS}

\section{Chinese SLOC development and its main features}

By the midst of 2000s, it is became an obvious fact that China is in the way to transform from the point of regional power to semiglobal power. Chinese export oriented strategy demands for sustaining its robust economic growth raw materials. By 1993 China is becoming oil importer country. Energy needs closely related with its intensive domestic growth, compelled PRC political leadership to develop and accept a new foreign policy strategy which is the one of the important parts of the Chinese foreign policy priorities. Approximately, by the end of $90 \mathrm{~s}$, China has become active participant in the global oil and more widely raw materials market participant. Chinese search for energy resources made its policy more active and notable in such geographically distant areas like Africa, to say precisely in Sub Saharan Africa, in the Middle East, in Latin America. All of these developing trade, economic, energy links have, indeed the complex influence on development of Chinese SLOC (Sea Lines of Communication) which is composed of various factions, among which are: commercial and military ships, development of various ports, security of SLOCs and its strategic impact.

Chinese development of Sea Power Strategy is preconditioned by two main factors: economic and military-strategic. Economic reasons and general preconditions were formed since time of Chinese economic growth became evident and undeniable fact. As was mentioned before, the period of $90 \mathrm{~s}$ can be measured as a starting point for resource diplomacy. Military-Strategic preconditions for SLOCs development is basically preconditioned by maritime tensions and US declared 'rebalancing' strategy toward Asia-Pacific where military component is pivotal. China possesses a large amount of territorial areas: coastline $18.000 \mathrm{~km}$, three million square kilometers of territorial seas, over 6.500 islands with an area larger than 500 square meters. November 8, 2012, at the 18th Party Congress of the Chinese Communist Party was accepted a strategy "building China into a sea power nation " [1]. Concept of the "building China into a sea power nation" is inherently has a multidirectional nature: utilization, protection, management, environmental protection, maritime sovereignty, ocean technologies and etc. [2]. 18 ${ }^{\text {th }}$ Party Congress statement's view on "building Sea Power Strategy" lately was affirmed by CCP's President Xi Jinping: “The $18^{\text {th }}$ Party Congress has 
set the important task of building China into a sea power nation. It is of great significance to implement the important task for promoting China's economic development in a sustainable and healthy way, safeguarding national sovereignty, security and developing interests, realizing the objective of building China into a well-off society in an all-round way and the rejuvenation of the Chinese nation. We must advance our concern for the ocean, understanding of the ocean, and administration over the ocean, so as to make new achievements to push forward the building of China into a sea power nation [3]. The term of "Sea Power Nation" has a strong mixed links with another concepts and foreign and security definitions: maritime sovereignty perspectives which are closely related to South China Sea territorial disputes and safety and normal functioning of the SLOCs in far distant areas and with alongside straits. The issues of the maritime disputes over national maritime sovereignty demands development of a strong modern Navy in order to defend Chinese sovereignty, rights and interests. [2]

The development of SLOC (Sea Lines of Communication) has obtained strategic importance and high government attention since the beginning of 2000s. After exhaustion of internal Chinese oil sources in North-Eastern areas of the country, by Beijing was accepted one of the perspectives Chinese foreign policy strategies aimed at different points of the world - "resource strategy". "Resource strategy" itself means Chinese search for energy and raw materials in Africa, Latin America, Central Asia, Middle East for sustaining of normal pastes for economic development. Strategy is based on making deals on mining of various sorts of raw materials such as oil, gas (Middle East and Central Asia) and non-ferrous and ferrous metals (sub-Saharan Africa). As a matter of fact, Chinese "Resource Strategy" and energy security are semi-identical terms in definition of its main characteristics. Against the background of some elements of this strategy, to say precisely, Beijing faces with issue of securing its SLOCs in order to make them effective in its performance and securing them. Here, the geographical factor plays a determinative role, because in such close areas like in Kazakhstan, Russia and Myanmar, China could rely on continental routes of delivery, pipelines in the case of oil and gas, and railway routes in the case of minerals. But in such remote areas, like Africa, Middle East and Latin America logistics and transportation strategy predominantly relied on tankers deliveries which are the inseparable part of SLOCs' components. Here, in this strategic point,
Chinese energy strategy and SLOC are closely linked to each other.

Term of the SLOC (Sea Lines of Communication) has a mixed understanding and it is composed of different concepts from different disciplines. Major components which make a general sense for SLOCs from disciplinary sciences: logistics and transport, maritime navigation, strategy and military. SLOC - it is a maritime route between ports for commercial, logistics and naval forces. SLOC plays a predominant transportation functions for delivering of trade goods from one point to another. Three main elements construct a SLOC: first, tankers; second, maritime geographical routes; third, ports. First element - tankers or in other words VLCC (Very Large Crude Carrier) is related to shipbuilding industry; second element - maritime routes on sea and straits where ships pass their way to certain ports, are related to geography and its locations in the World Ocean areas; and the last, third element - ports related to transportation hubs which perform various sorts of cargoes their delivery capacity. And as a final tendency- it is a development of further more complex and advanced blue water naval capabilities. All of the blended tendencies and issues became in central of Beijing 's considerations over SLOC development since last decade.

With increasing oil dependency and probable imports rising to 80 percent by 2025 [4] for China is becoming important to make a good management over its tanker fleet and its capacity for oil and other resources transportation in technical capabilities terms and also general management issues. As mentioned in Andrew Erickson and Gabe Collins's article: "Beijing`s Energy Security Strategy: The Significance of a Chinese State-Owned Tanker Fleet" major role in the determination of Chinese strategy regarding tanker development is the issue of domestic production and construction a state-flagged tankers oil fleet capable of hauling up to three-quarters of Chinese oil imports by $2020[5,6]$.

Development of tankers shipbuilding industry has a complex measures in the context of SLOC development. Here, it could be classified on directions of the commercial management, construction and technologies and its place and significance in sustaining of energy security. As mentioned by Xinhua News Agency and China Daily 60 percent of oil imports are carried by Chinese shipping companies. As was mentioned by a senior official at the Ministry of Communications` Water Transport Department, Peng Cuihong, that it is need to build additional oil tankers to reduce reliance on foreign tankers [7]. A clear position in this sense is described by China 
Daily: ....as the world's second largest oil importer, our overseas supplies are vulnerable. Inadequate ocean shipping capacity is a weakness that could prove fatal. We have cause for worry with around 85 percent of our entire oil imports transported by foreign-flag vessels. This is acceptable when business is just business. But we are not in a perfect world. The best way to minimize our vulnerability is to increase our preparedness for less than normal times. It is well within our reach to have more than 60 percent of our oil imports carried by Chinese-flag tankers, if that is what we need for oil security. The government should not economize on this strategic national interest. It has the financial resources to make it happen. The subsequent shipbuilding orders will in turn be a major boost to home shipyards. The authorities' idea to encourage more domestic shipping companies to enter the ocean- faring business is a good one... We can also handle the technology. Several domestic shipyards have been building large crude oil carriers for years. We applaud the Ministry of Communications' determination to upgrade our self-reliance in ocean shipping. It is an insightful decision that will help guarantee a more comfortable position in the kind of special times we hope never come [8]. Especially these both thesis's taken their confirmation after announced US "Rebalancing strategy" where military component plays a central role.

As mentioned in Luo Ping's article "National Oil, Nationally Hauled: China's Energy Security Insurance Line" by 2010 Beijing intends to transport 40-50 percent of its oil imports in PRC-flagged states, then by 2020 this number will be increased to $60-70$ percent, also is calculated that by 2010 in order to sustain normal transportation would be need more than forty VLCCs (Very Large Crude Carrier) which would be able to carry of 1.5 million barrels of oil [9].

Management issues as well as directly related to VLCC relations. Here, can be mentioned parallels with energy sector of China. Energy security is a primary objective in the hand of state control in order to sustain formidable control and management over vital patters. Chinese energy strategy is realized by leading state-owned companies like CNPC, Sinopec, CNOOC, PetroChina, Sinochem and etc. Some difference led between oil and its transportation in the state control. Oil issues is regulated and managed by state companies meanwhile maritime transportation has a diverse base with cooperation of private companies. In this context, some Chinese scholars state that tankers shipbuilding industry would be suited under the state control. General question rising in this context it is stand points dedicated to management, does it have a commercial base or does it have state strategic control? By the midst of 2000s 90 percent of China`s oil shipping capacities were served by foreign vessels [10]. For China it would be necessary more than 40 VLCCs to satisfy its goals of carrying 50percent of imports by Chinese tankers by 2010 [10, p.671]. Last but not least role is influenced by distance of transportation which in its turn demand high costs for realization, thereby preferring foreign VLCC for performing transport missions [11].Approximately since the midst of 2000, China's shipyards and development of PRC- flagged tankers became identical to state- owned oil companies in their management style confirming its strategic importance. Role of the domestic ports in handling with energy security and transportation is dedicated to increase its amount of carried crude. For instances, in the midst of 2000s, only three ports - Qingdao, Zhoushan, and Shuidong - could directly berth tankers displacing 200,000 DWT or more, such as the VLCCs that deliver crude from Africa and the Middle East. Consequently, China is rapidly preparing specialized facilities at Ningbo, Quanzhou, and Maoming on China's southeast coast to handle 200,000-250,000 DWT oil tankers. Introducing of new facilities, like a pipeline with improve transportation of crude and as a result will boost energy security [12].

As a conclusion, we may think that Beijing in its tankers' dilemma faces with following significant issues: first, management issues which related with state or private participation in business dealings, from one point it is an influence of commercial factor and cooperation regulated by market and another point is a state control in which transporting of crude is a vital for state's energy security. In technical issues, there is a question about DWT tankers, development of their manufacture on the bases of domestic shipyards and increasing of PRC-flagged VLCCs capable for transporting sufficient number crude necessary for China's energy consumption.

Another significant components of SLOC strategy are related to geographical dimension measured by straits through which tankers pass their way to home and again and ports. The significance of ports in this sense is determined by cargo sort, in the context of SLOC it is predominantly African ports where large amount of crudes, minerals are embarked into tankers and other transportation vehicles. Dilemma of straits in the Chinese SLOC development has a political and military- technical development features due to the determinative fact of US 7th fleet station in Malacca Strait and strategic necessity for develop 
a sufficient portion of naval forces capable to secure maritime routes to various ports. In geographic dimension under PRC it is the issue how to make this transportation route more comfortable and safe for getting of Chinese routes. This question in the view of Chinese politicians, militaries and academicians has a political character. Ever, in last decade, during Bush administration policy, especially when it was concentrated in the Middle East, PRC pay attention that US and its allies would be able to blockade Malacca strait in the case of hypothetical crisis or conflict. This fact itself gave an impetus for searching of alternative routes. Two were found Gwadar port in Pakistan, connecting with Indian Ocean in south and till north to Pakistani- Sino border. Severity of this way, it is a mountain area and that final cargo would be delivered in western edge of China, with probability that this way takes a long time. Another direction, not so populous, led through Arctic ocean. In this geographic area, cooperation is predominantly in transportation made with Russia [13]. But due to suitability, comfort ability Malacca remains a predominant oil shipping route due to the costs (in additional time, fuel, and ships) [12].

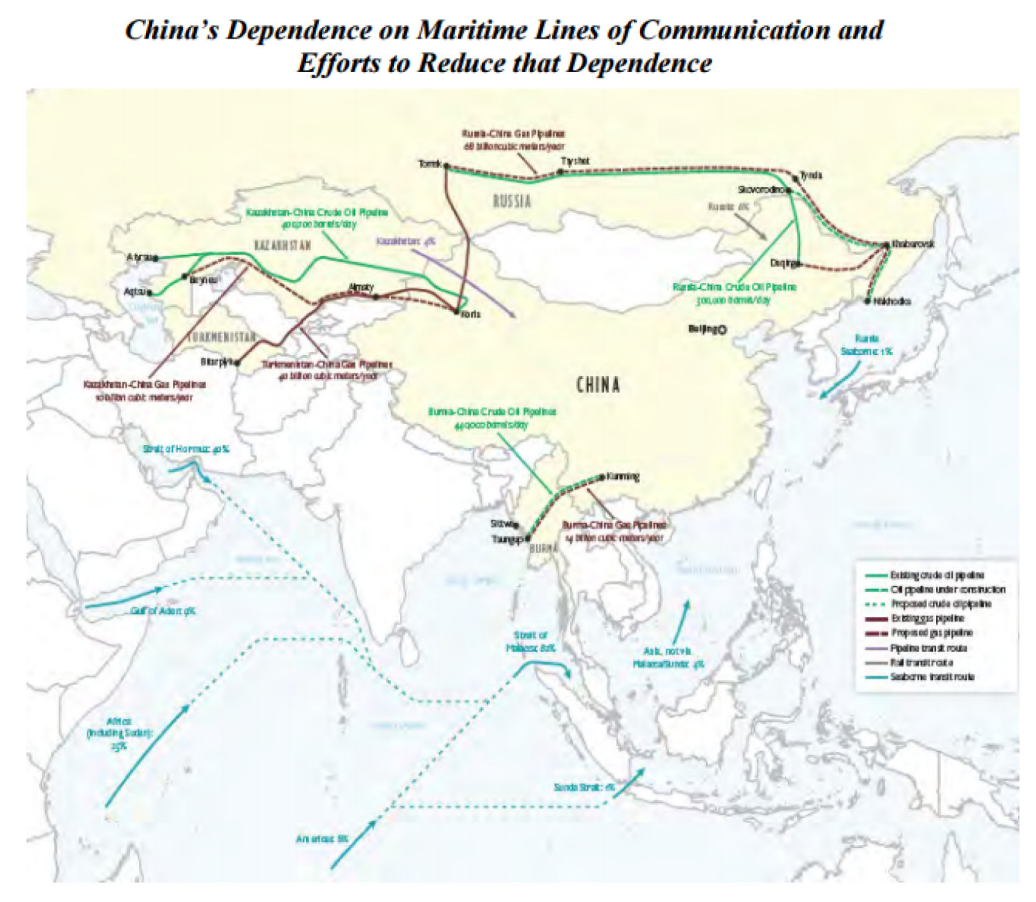

Source: DoD, Report to Congress on Military and

Security Developments Involving the People`s Republic of China 2012, May, p.37

Beijing since 1990s when it reshaped its foreign policy priorities toward Africa based on clear economic- energy cooperation. In Chinese economic strategy in Africa, due to Africa's destroyed and underdeveloped infrastructure, China realizes not only mining but also infrastructure projects dedicated for African nations domestic development and for sustaining its energy project in the region. Here, in China's Africa strategy, one of the significant consideration is prioritized to ports and hub development in their technical capabilities. Ports in geographical location are located along Africa's eastern and western littorals. There are following ports: Takoradi (Ghana), Kribi (Cameroon), Lobito (Angola), Lekki (Nigeria), Lome (Togo), Conkary and Boffa (Guinea), Abidjan (Côte d'Ivoire), Djibouti (Djibouti), Pointe Noire (Congo- Brazzaville), Walvis Bay (Namibia), Richard Bay (South Africa), Mombasa and Lamu (Kenya), Bagamoyo (Tanzania). To show how China pays attention on ports development, it would be better to show the amount of investments which were invested in that area: in Mombasa (Kenya) in summer 2013 China and Kenya signed a $\$ 5$ billion contract for which China will finance the construction of a railway connecting Uganda and Mombasa ports. In Lamu Pot (Kenya) the Chinese company China Communications Construction Company (CCCC) will construct its first three berths, port project itself costs $\$ 484$ million. In Abidjan, Cote d'Ivore Chinese company China Har- 
bor Engineering Company (CHEC) signed a $\$ 933$ million construction with the Abidjan Port Authority. Before that event, in July 2012 PRC government announced on $\$ 5$ billion investment.[14].

2. Impact of SLOC development. String of Pearls strategy

Chain of Chinese energy supplies from Africa and the Middle East demands Beijing to consider a more complex and new strategic phenomenon within Chinese foreign policy process. Once emerged as a labels of accumulated new Chinese power phenomenon's like "Beijing's consensus" and "Resource diplomacy" puts "String of Pearls" "strategy among these actual trends of regional and global politics.

Phenomenon of SLOC development in overall Chinese foreign and strategic policy is extended in its nature, Chinese SLOC development got name "String of Pearls" strategy which was created by US Air Force Lt. Col. Christopher J. Person and realized in July 2006. The major idea of this thesis, placing China into Indian Ocean and subsequently placing Indian Ocean in the central place of ongoing political and strategic shifts within regional security. By the time of this article writing in time comparison, it could be identified two main periods of Chinese SLOC development, every period with its own feature: first, midst of 2000, in which politicians and strategic thinkers, first of all Chinese, identified significance of supply chain for sustaining of economic growth and recognizing the fact that this issue possesses great importance for state's security patterns on a par with energy security, military modernization, territorial integrity and sovereignty. [15] Second period, can be considered since 2011, when Barack Obama's administration officially announced its "Pivot to Asia" or in other words "Rebalancing strategy" toward Asia Pacific. Main obstruction rising for China 's SLOC strategy development in the view of "rebalancing" is led that "rebalancing strategy" is composed of huge US military assets dispersed and deployed within a network of US facilities in Asia- Pacific area. The factor of US permanent presence in Asia Pacific compels Beijing to reconsider its SLOC security strategy in terms of security dilemma and further consequences.

Impact from Chinese SLOC development has substantially blended nature with three major concurrent tendencies: first, Chinese strategic aspirations toward its SLOC development in the IOR; second, SLOC as a driving force for PLAN modernization and, third, common strategic situation around the IOR in the context of Asian power ascendancy (China, India).
Strategic conditions around SLOC development are constructed around the IOR/ Western part of Asia- Pacific. Approximately 80\% oil imported oil is supplied through maritime routes within the IOR and $85 \%$ of supplied resources pass through Malacca strait.

Some of the Chinese analysts on related issues such as foreign policy, maritime strategy, naval development state that contemporary period of China's development path is predominantly maritime and maritime development is put forward as a great state priority [15]. In political decision- making management, Chinese groups are divided into two camps, advocating for one or the other policy priorities: the "free marketers" who advocate for commercial base for transporting of crude by cooperation with foreign servers. This group of thinkers, in terms of sustaining oil security supply chain, appeal for US navy presence around the world ocean as a guarantor for Chinese ships passing the way from ports to home. Another group of thinkers is presentenced by "mercantilists" who see shipping as a part of branches of state power which should be under state's control for sustaining main the security of the state. In their view, production and possession of tankers must be under state's management and in terms of foreign policy, according to "mercantilists" maritime oil security is considered under zerosum game perception [15, p. 51].

Common strategic situation around the IOR is constructed by maritime routes, straits through which Chinese ships oilers pass and ports where they assume crudes, cargoes and where they deliver it. Areas where these actions are spread are parts of new security environment, there are: Indian Ocean composed of Arabian Sea, Bay of Bengal, Andaman Sea, Gulf of Thailand and South China Sea. Central role in this geographical location is given to Malacca strait through which is passed a significant amount of crude not for China only but for the other East Asia energy consumption nations - South Korea and Japan. These maritime routes define a network of security environment which in future will be created for PLAN naval developments.

Common security environment within the IOR is defined by two influential factors: Indo-Pakistani local conflict caused by Kashmir and which are able to spread to littoral adjacent areas and last, second factor is defined by recently announced US "rebalancing strategy" networking security links into one regional security complex. Here, "Rebalancing strategy" itself means an engagement of regional power such as India toward a new security network linked with the center of US. Due to the complexity 
of the "Rebalance strategy" nature, it means that third non regional- habitants power like Japan and US can be involved. Here, geopolitically South Asia security bounded on Indo-Pakistani conflict makes a complex network with other power engagement: China as a Pakistani ally, US as a Indian security partner and plus Japanese engagement. In the case of political crisis, Indo-Pakistani military clashes could occur in adjacent Himalayas area and around littoral areas. India, despite its geographic vastness can be surrounded by Pakistan and China in North and if Chinese will be boosted in sufficient level, Chinese engagement will be posed from South. If calculate the situation in terms of military strategy, within the IOR, security construction is posed by the Indo- Pakistani conflict ranging in its military utility [16], from nuclear to conventional warfare, as a permanent factor and second incrementally developing factor, probable increasing presence of PLAN which can shift a regional balance in favor of SinoPakistani alliance.

Another, great event related to SLOC development it is a Chinese military modernization program. As it was noted before, some of Chinese analyst emphasize that Ocean became a part of China's contemporary development, paying attention for trade and economic development relied on the sea. In this case SLOC became a driver for PLAN modernization process. This complex process itself has a doctrinal and tangible changes within Chinese security thinking process.

Here, in this strategic context, where many prominent Chinese political leaders within CCP and academic circles report on vitality of the Ocean and related to it patterns for China's XXI century development. [2] In military-strategic level, China made a huge reorientation for its military forces priority development. The threat of massive conventional invasion has disappeared since the collapse of the USSR, and main apparent objectives of China's regional security issues became concentrated around maritime disputes in East Asia and South-East Asia and Taiwan's independence contingency. These foreign policy factors became a precondition and gave an impetus for the general course of PLA development and taking into account geographical environment, the development of Navy is the one of the main preoccupations of PRC army modernization. In common strategic level, Beijing faces with two strategic developments within its forces modernization. This strategic condition can be divided into two areas: Western Pacific and Indian Oceans respectively. In the area of Western Pacific, China is driven by clear security patterns competition with Japan, some ASEAN nations and in some extent with the United States. Here, PLAN activity and its ability to conduct operations is defined by geographical scopes as a First Island Chain which encompass Japan, South Korea, Taiwan, the Philippines and Indonesia. The Second Island chain strengthens from the Japanese archipelago, including Mariana Islands, through Guam to the eastern borders of Indonesia [17]. PLAN modernization for the IOR (Indian Ocean Region) is basically motivated by boosting its energy security links, lifeline roots which linking China with Middle Eastern and African crude importers countries. For these conditions, PLAN construct its forces to be able to correspond appropriately in the event of crisis or conducting of operations for escorting tankers and another maritime vehicles.

In the course of the late military modernization program, in order to sustain SLOC security, major priority is given for PLAN blue water capabilities to be able to handle with various missions in the open sea and Air Forces that can sustain conducting maritime operations. It was a tendency, especially in 90s where Navy and Air Forces together performed maritime operations, by the 2010s, PLAN became more independent in its operational utilities [18 Strategic Asia 2012-13 China`s Military Challenge]. Protection of SLOCs demands an introduction of nuclear attack submarines (SSN) and surface combatants. PLAN modernization is the question of how many units of Navy forces will be introduced and their utilities, for instances in order to conduct missions with disputed areas China needs other types of surface combatants, in order to conduct missions in the IOR will be another.

\section{Conclusion}

Development of China's SLOC within the IOR has not only economic nature but entails a strategic significance for sustaining Chinese economic development and as a result of its comprehensive national power. In this sense, there is growing of Chinese influence in the IOR, in confines of "String of Pearls" areas. Basic question which constitute the problem is that what kind of further trajectories will be in the development of Chinese invested ports across "String of Pearls" areas. Here, the main question on Gwadar and Sri Lanka ports infrastructure development, will it be economic or after sometime it will have a military characteristics and utilities. More Chinese assertive and steady policy in this direction could halt its 
"peaceful development" policy or in other extent the development of military component of SLOC is confined by its proclaimed "peaceful development" foreign policy doctrine [18]. In the case of transport and logistics development and building military capacities to be able to handle SLOC security, and political passivity of India, US, the IOR could became zone under Chinese influence which indicates its rising geopolitical influence across "Strategic Asia".

\section{References}

1 Report of Hu Jintao to the 18th CPC National Congress, China.org.cn, November 16, 2012, http://www.china.org.cn/ china/18th_cpc_congress/2012-11/16/content_27137540_8.htm

2 China's "Sea Power Nation" Strategy Wu Xiaoyan http://isdp.eu/content/uploads/images/stories/isdp-main-pdf/2014-wuchinas-sea-power-nation-strategy.pdf

3 Xi Jinping, "We Must Advance Our Concern for, Understanding of, and Administration Over the Ocean, " The Central People`s Government of the People`s Republic of China, July 31, 2013, http://www.gov.cn/ldhd/2013-07/31/content 2459009.htm

4 Office of the Secretary of Defense, Military Power of the People`s Republic of China 2007, Annual Report to Congress, p. 8 //https://fas.org/nuke/guide/china/dod-2007.pdf

5 Andrew Erickson and Gable Collins "Beijing`s Energy Security Strategy: The Significance of a State-Owned Tanker Fleet" //http://connection.ebscohost.com/c/articles/26584858/beijings-energy-security-strategy-significance-chinese-state-owned-tankerfleet

6 Qiao Enyan, "Petroleum Enterprises and Their Use in National Oil Security Strategy", Modern Chemical Industry, July 2005, pp.9- 12

7 "China Must Carry 60\% of Seaborne Oil Imports on Local Shippers", Xinhua Financial Network News, June 14, 2007

8 Oil Security at Sea, " China Daily, June 14, 2007 // http://www.chinadaily.com.cn/

9 Luo Ping, "National Oil, Nationally Hauled: China’s Energy Security Insurance Line" (Guoyou Guoyun: Zhongguo Nengyuan de Anquan Baozhang Xian), Maritime China, February 2005, pp. 38-40.

10 "China Urged to Beef Up Ocean Oil Shipping," Asia Pulse, March 15, 2006. //http://www.ogj.com/articles/print/volume-104/issue-38/general-interest/china-seeks-oil-security-with-new-tanker-fleet.html

11 Ren Xiaoyu, "Analysis and Opinions on How PetroChina Markets Its Equity Oil," China Oil and Gas, 2002, pp. 50-52// http://www.ogj.com/index.html

12 Andrew Erickson and Gabe Collins Beijing`s Energy Security Strategy: The Significance of a Chinese State-Owned Tanker Fleet p. 675 // http://connection.ebscohost.com/c/articles/26584858/beijings-energy-security-strategy-significance-chinese-stateowned-tanker-fleet

13 Interview with scholar on energy security: Rovshan Ibrahimov 09.06.2016

14 China in the African Ports: A String of Pearls in the Making? Marc Casabayo and Roger Greatrex p. 23 // https://lup.lub. lu.se/student-papers/search/publication/8852087

15 Gunboats for China's New "Grand Canals"? Probing the Intersection of Beijing`s Naval and Oil Security Policies Andrew Erickson and Lyle Goldstein //www.andrewercikson.com/2009/04/gunboats-for-china-' grand-canals'-probing-the-intersection-ofbeijing s-naval-and-energy-security-policies/

16 Anthony H. Cordesman, Abdullah Toukan, Michael Wang, Eric P. Jones The Indian Ocean Region: South Asia Subregion // CSIS, 24.4.2016 P. $14-16$

17 Andrew S. Erickson, Gabriel Collins China`s Maritime Evolution: Maritime and Commercial Factors p. 59 // http://www. inhacis.com/zeroboard/data/krback/1207813097/03_Ericson.pdf

18 Prem Mahadevan, China in the Indian Ocean: Part of a Larger PLAN //http://www.css.ethz.ch/content/dam/ethz/specialinterest/gess/cis/center-for-securities-studies/pdfs/CSSAnalyse156-EN.pdf 